\title{
The synthesis in vivo of proteins in various tissues in chickens adapted to intermittent feeding*
}

\author{
BY Y. PINCHASOV† AND I. NIR \\ Department of Animal Science, Faculty of Agriculture, The Hebrew University of \\ Jerusalem, Rehovot 76-100, Israel
}

AND ZAFRIRA NITSAN

Department of Animal Science, Agricultural Research Organization, The Volcani Center, P.O. Box 6, Bet Dagan 50-200, Israel

(Received 22 December 1987-Accepted 25 April 1988)

\begin{abstract}
1. Protein synthesis was estimated in vivo in breast (superficial pectoral) and tibia (gastrocnemius) muscles, liver, kidney, pancreas, crop, duodenum, jejunum and ileum, using L-[U-14 C]lysine injection. The effect on incorporation of $\left[{ }^{14} \mathrm{C}\right]$ lysine 1 and $2 \mathrm{~h}$ after injection was examined in five chickens adapted or not adapted to intermittent feeding.

2. Incorporation of $\left[{ }^{14} \mathrm{C}\right]$ lysine into tissue decreased in magnitude in the following descending order: pancreas $>$ jejunum, duodenum $>$ ileum, crop, liver $>$ kidney $>$ tibia, breast muscle and blood plasma.

3. The incorporation of $\left[{ }^{14} \mathrm{C}\right]$ lysine into muscle protein was higher in chicks after $24 \mathrm{~h}$ of refeeding than after $24 \mathrm{~h}$ of food deprivation. These differences were higher in adapted than in non-adapted birds. On days of refeeding the rate of incorporation exceeded that found in chickens fed ad lib.

4. Bound ${ }^{14} \mathrm{C}$ from lysine in the intestinal segments was less than in control birds after food deprivation and greater after refeeding in non-adapted chicks only.

5. A negative relation was observed between bound and free ${ }^{14} \mathrm{C}$ in muscles and in other tissues.

6. Short- and long-term adaptations to feeding regimens are discussed.
\end{abstract}

Intermittent feeding is accompanied by enhanced degradation of certain body tissues on the day of food removal, and by increased deposition of body fat and protein on the day of refeeding (Nir \& Nitsan, 1979; Pinchasov et al. 1985). It was shown recently (Pinchasov et al. 1985) that the rate of body growth or protein deposition in intermittently fed birds on days of refeeding was double that of ad lib.-fed chicks.

The accumulation of muscle proteins is the outcome of the difference between the rate of protein synthesis and degradation. From studies in vivo (Sunde et al. 1984; Kang et al. 1985 ) it was suggested that the growth of skeletal muscle in chicks is achieved mainly by slight changes in synthesis rate and by marked alteration in degradation rate. The purpose of the present work was to study the protein synthesis rate in vivo in various organs of broiler chicks and to clarify the significance of the metabolic adaptation in protein synthesis of birds fed every other day. Protein synthesis in vivo was examined in various organs of chicks adapted or not adapted to intermittent feeding.

\section{MATERIALS AND METHODS}

Commercial meat-type chicks ( $1 \mathrm{~d}$ old) were reared in battery cages, and fed on a commercial starter diet in a crumble form (216 g protein and $12.5 \mathrm{MJ} \mathrm{ME} / \mathrm{kg}$ ), formulated

\footnotetext{
* Contribution from the Agricultural Research Organization, The Volcani Center, Bet Dagan, Israel. No. 1963-E, 1986 series.

$\dagger$ Present address: Department of Poultry Science, University of Georgia, Athens, GA 30602, USA.
} 
according to the National Research Council (1977). Food and water were available ad lib. until the start of the experiment.

At $12 \mathrm{~d}$ of age the chicks were divided into three treatment groups, with four replicates per treatment. The control (C) birds were fed ad lib. the treated birds were fed intermittently: food was removed (depleted, D) or restored (repleted, R) every other day. Autopsies were carried out at 27 and $28 \mathrm{~d}$ of age, after eight cycles of intermittent feeding, and on the same days other chicks which had been exposed only to one cycle of intermittent feeding (non-adapted DN and RN chicks respectively) were also autopsied. At this age body-weights (BW) without the contents of the gastrointestinal tract were (g): C 680 , DN 572, RN 670, D 449 and R 545.

In order to determine the rate of incorporation of $\left[{ }^{14} \mathrm{C}\right]$ lysine with time, a preliminary study with eight chickens, weighing approximately the same as the control chickens, was carried out. The incorporation of $\left[{ }^{14} \mathrm{C}\right]$ lysine into breast and leg muscle protein was measured $0 \cdot 5,1$ and $2 \mathrm{~h}$ after injection. In view of the results, in which the incorporation rate of $\left[{ }^{14} \mathrm{C}\right] l y s i n e$ increased linearly $2 \mathrm{~h}$ after the injection (Fig. 1), it was decided in the current study to measure the incorporation 1 and $2 \mathrm{~h}$ after injection.

Before the injection, birds were kept in replicated groups and eight birds per treatment were taken for the injection (five treatments $\times$ two periods $\times$ four birds, i.e. a total of forty birds). Birds were injected intraperitoneally with a solution of $\mathrm{L}-\left[\mathrm{U}-{ }^{14} \mathrm{C}\right]$ lysine hydrochloride ( $348 \mathrm{mCi} / \mathrm{mmol}$, Amersham International, Amersham, Bucks) diluted with saline $(9 \mathrm{~g}$ sodium chloride/1) to give a concentration of $10 \mu \mathrm{Ci} / \mathrm{ml}$. A single intraperitoneal injection was given in a dose of $1 \mu \mathrm{Ci} / \mathrm{kg} \mathrm{BW}$ per bird. The birds were injected sequentially in treatment order, every $2 \mathrm{~min}$. Injections were given between 10.00 and 14.00 hours to minimize diurnal variation. Before killing, blood was drawn by heart puncture with a heparinized syringe. The blood was transferred to ice-cold centrifuge tubes, centrigued at $4^{\circ}$ for $10 \mathrm{~min}$ at $2500 \mathrm{~g}$ and, after separation, the plasma frozen at $-20^{\circ}$. The breast (superficial pectoral) and tibia (gastrocnemius) muscles, the liver, kidney, pancreas and gastrointestinal tract (GIT) were removed immediately, the GIT was emptied and all the organs were wrapped in aluminium foil and frozen in liquid $\mathbf{N}_{2}$.

Measurement of protein synthesis was carried out essentially as described by Larbier \& Perrot (1984). From the frozen organs, a representative sample from the same location in each organ was weighed, homogenized for $10 \mathrm{~s}$ in trichloroacetic acid (TCA; $100 \mathrm{~g} / \mathrm{l})$ with an Ultra-Turrax homogenizer and centrifuged at $2500 \mathrm{~g}$ at $4^{\circ}$ for $15 \mathrm{~min}$. The supernatant fraction was decanted, washed with ethyl ether, and a portion was transferred to scintillation vials for counting of radioactivity. The precipitates were washed and centrifuged four times with TCA solution, resuspended in ethyl ether, centrifuged and airdried. The dry precipitate was redissolved by adding 1-2 $\mathrm{ml} 1 \mathrm{M}$-sodium hydroxide and leaving at $70^{\circ}$ for $4-8 \mathrm{~h}$. The solution was transferred to scintillation vials, $15 \mathrm{ml}$ scintillation solution (Packard, emulsifier Scintillator $299^{\mathrm{TM}}$ ) was added to each vial, and radioactivity counted (Beckman LS-7800). Quench corrections were made by external standardization, and the results were calculated as disintegrations/min per $\mathrm{g}$ tissue. Plasma proteins were precipitated with sulphosalycilic acid $(20 \mathrm{~g} / \mathrm{l})$, centrifuged and transferred to scintillation vials as described previously.

Statistical analyses were carried out by the procedure set out in the Statistical Package for the Social Sciences (SPSS, Version 8; Nie et al. 1975). Determination of the significance of treatment, period of incorporation and interactions was carried out by two-way analysis of variance; differences between treatments within periods were assessed by Duncan's multiple-range test. 


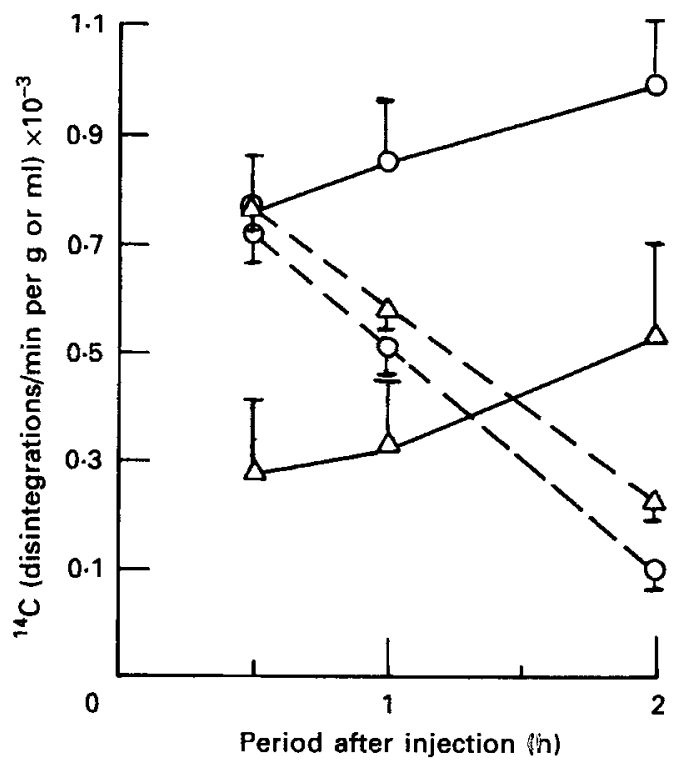

Fig. 1. Bound $(-)$ and free $(---)\left[{ }^{14} \mathrm{C}\right]$ lysine level in breast $(\mathrm{O})$ and tibia $(\triangle)$ muscles, $0 \cdot 5,1$ and $2 \mathrm{~h}$ after injection. Eight birds fed $\mathrm{ad}$ lib. were each given a single intraperitoneal injection of $\left[{ }^{14} \mathrm{C}\right] \mathrm{lysine}$, values are means with their standard errors represented by vertical bars.

\section{RESULTS}

In the preliminary study, the incorporation of $\left[{ }^{14} \mathrm{C}\right]$ lysine increased linearly from 0.5 to $2 \mathrm{~h}$ in breast and tibia muscles (Fig. 1). It was higher in breast than in tibia throughout the experimental period. The level of free $\left[{ }^{14} \mathrm{C}\right] \mathrm{lysine}$ in breast and tibia decreased linearly with the time-period after injection (Fig. 1). The incorporation of ${ }^{14} \mathrm{C}$ from lysine was highest in the pancreas, followed by jejunum, duodenum $>$ ileum, crop, liver $>$ kidney $>$ tibia and breast muscles and blood plasma (Table 1).

In breast and tibia muscle, the level of bound ${ }^{14} \mathrm{C}$ in protein increased from 1 to $2 \mathrm{~h}$ after injection in all treatment groups (except DN for breast muscle). The incorporation was significantly higher in chicks after $24 \mathrm{~h}$ of refeeding than after $24 \mathrm{~h}$ of food deprivation, and higher in birds adapted than non-adapted to intermittent feeding (Table 1). The level of free $\left[{ }^{14} \mathrm{C}\right] l y s i n e$ decreased $2 \mathrm{~h}$ after the injection (Table 1 ). In the tibia muscle the free $\left[{ }^{14} \mathrm{C}\right] l y s i n e$ was higher in D and DN chicks than in C, and in the R and RN chicks was not significantly different from that in control birds.

In blood plasma, the level of bound $\left[{ }^{14} \mathrm{C}\right]$ lysine in protein increased significantly from 1 to $2 \mathrm{~h}$ after injection in DN and D groups only and was higher in the D group than in those having access to food $(C, R N, R)$. The level of free $\left[{ }^{14} \mathrm{Clysine}\right.$ decreased $2 \mathrm{~h}$ after the injection in all treatment groups. It increased significantly above that in control birds in DN but not in $\mathrm{D}$ chicks, and decreased to less than that in controls in $\mathrm{R}$ and $\mathrm{RN}$ chicks. In the liver, there were no significant treatments or period effects on the level of bound $\left[{ }^{14} \mathrm{C}\right]$ lysine but the free $\left[{ }^{14} \mathrm{C}\right]$ lysine level was significantly affected by both treatment and period in a manner similar to that in blood plasma.

In the kidney, the level of bound $\left[{ }^{14} \mathrm{C}\right]$ lysine was not affected consistently by time after injection (Table 1). The level in control groups was similar to that in the intermittently fed birds. In non-adapted chicks the incorporation of $\left[{ }^{14} \mathrm{C}\right]$ lysine was significantly higher after refeeding (RN) than after food deprivation (DN). The level of the free $\left[{ }^{14} \mathrm{C}\right]$ lysine decreased 


\section{Y. PINCHASOV AND OTHERS}

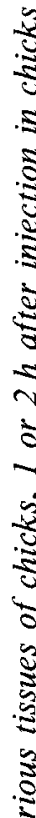

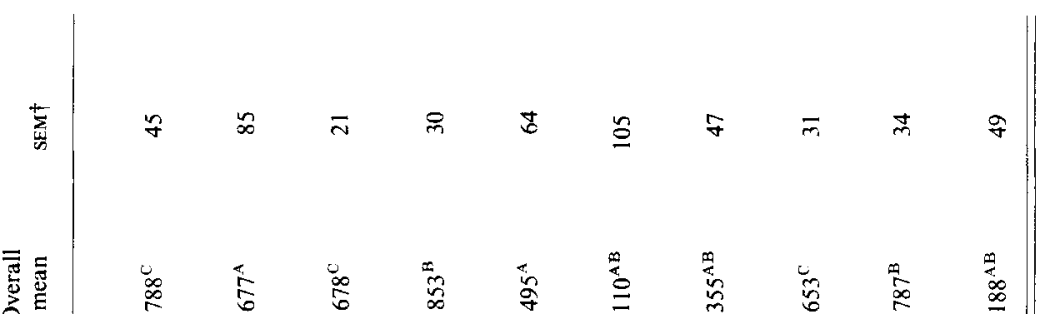

产

获

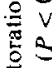

要

象象官

至言证

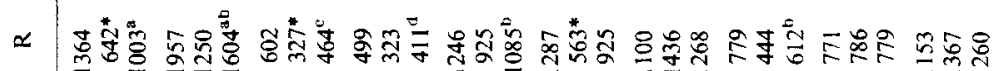

总象

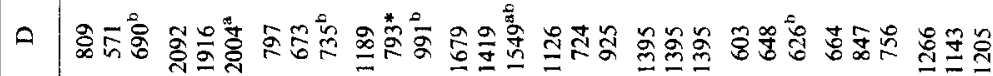

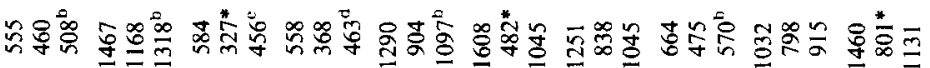

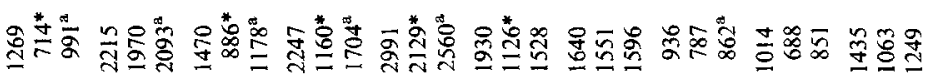

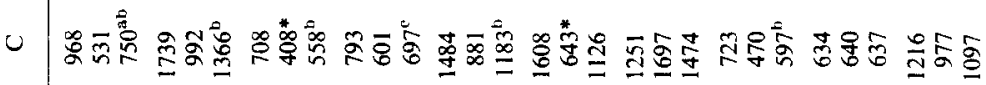

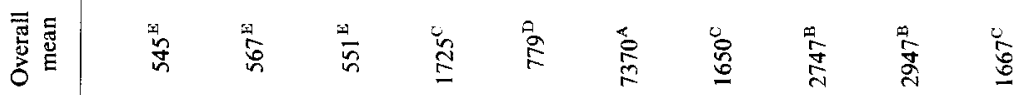

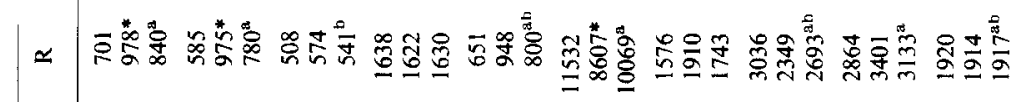

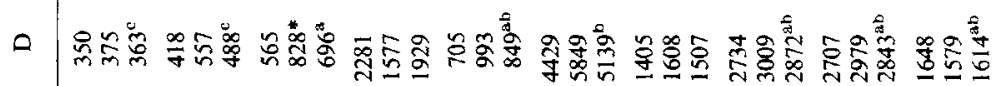

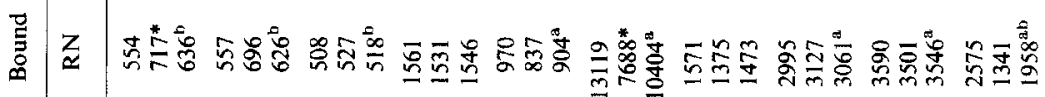

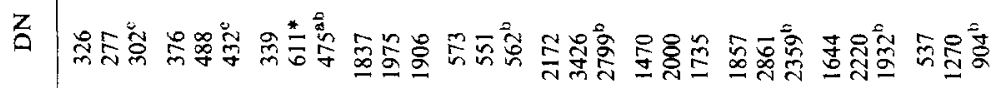

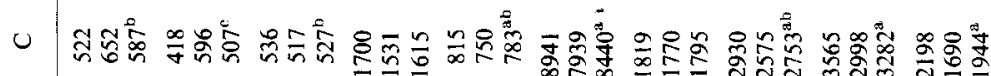

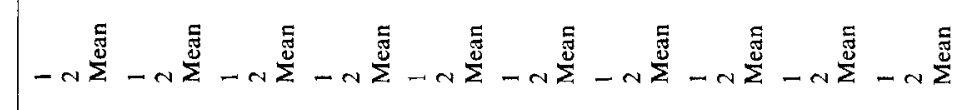

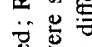

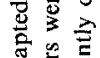

飠

흘

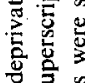

尊焉

只穿

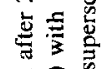

迹

过

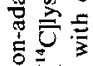

음

ธี

苋范

总言弯

용

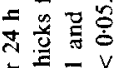

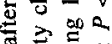

强

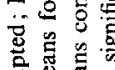

哥要要

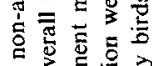

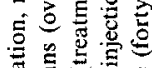

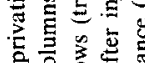

둥

可可

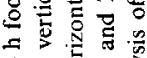

范白

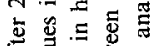

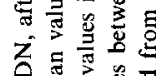

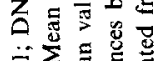

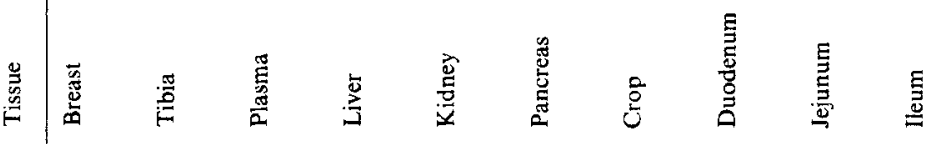

茯 
Table 2. Bound:free $\left[{ }^{14} \mathrm{C}\right]$ lysine in various tissue of chicks (means of 1 or $2 \mathrm{~h}$ after injection) in chicks fed ad lib. or intermittently

\begin{tabular}{llllllll}
\hline Tissues & C & DN & RN & D & R & Mean & SEM $\dagger$ \\
\hline Breast & $0 \cdot 78^{\mathrm{ab}}$ & $0 \cdot 30^{\mathrm{b}}$ & $1 \cdot 25^{\mathrm{a}}$ & $0 \cdot 52^{\mathrm{ab}}$ & $0 \cdot 83^{\mathrm{a}}$ & $0 \cdot 69$ & $0 \cdot 02$ \\
Tibia & $0 \cdot 37$ & $0 \cdot 20$ & $0 \cdot 47^{\mathrm{a}}$ & $0 \cdot 24$ & $0 \cdot 48$ & $0 \cdot 33$ & $0 \cdot 01$ \\
Plasma & $0 \cdot 94^{\mathrm{b}}$ & $0 \cdot 40^{\mathrm{b}}$ & $1 \cdot 13^{\mathrm{a}}$ & $0 \cdot 94^{\mathrm{ab}}$ & $1 \cdot 16^{\mathrm{a}}$ & $0 \cdot 81$ & $0 \cdot 02$ \\
Liver & $2 \cdot 31^{\mathrm{a}}$ & $1 \cdot 11^{\mathrm{b}}$ & $3 \cdot 33^{\mathrm{a}}$ & $1 \cdot 94^{\mathrm{b}}$ & $3 \cdot 96^{\mathrm{a}}$ & $2 \cdot 02$ & $0 \cdot 08$ \\
Kidney & $0 \cdot 66^{\mathrm{ab}}$ & $0 \cdot 21^{\mathrm{b}}$ & $0.82^{\mathrm{a}}$ & $0 \cdot 54^{\mathrm{b}}$ & $0 \cdot 73^{\mathrm{ab}}$ & $0 \cdot 52$ & $0 \cdot 02$ \\
Pancreas & $7 \cdot 49^{\mathrm{a}}$ & $1 \cdot 83^{\mathrm{b}}$ & $9 \cdot 95^{\mathrm{a}}$ & $5 \cdot 55^{\mathrm{b}}$ & $10 \cdot 8^{\mathrm{a}}$ & $6 \cdot 63$ & $0 \cdot 56$ \\
Crop & $1 \cdot 21^{\mathrm{a}}$ & $1 \cdot 08^{\mathrm{b}}$ & $1 \cdot 40^{\mathrm{a}}$ & $1 \cdot 08^{\mathrm{b}}$ & $1 \cdot 37^{\mathrm{a}}$ & $1 \cdot 21$ & $0 \cdot 04$ \\
Duodenum & $4 \cdot 61^{\mathrm{ab}}$ & $2 \cdot 73^{\mathrm{b}}$ & $5 \cdot 37^{\mathrm{a}}$ & $4 \cdot 58^{\mathrm{ab}}$ & $4 \cdot 40^{\mathrm{a}}$ & $4 \cdot 20$ & $0 \cdot 15$ \\
Jejunum & $5 \cdot 15^{\mathrm{a}}$ & $2 \cdot 27^{\mathrm{b}}$ & $3 \cdot 87^{\mathrm{b}}$ & $3 \cdot 76^{\mathrm{b}}$ & $4 \cdot 02^{\mathrm{b}}$ & $3 \cdot 74$ & $0 \cdot 12$ \\
Ileum & $1 \cdot 77^{\mathrm{a}}$ & $0 \cdot 72^{\mathrm{b}}$ & $1 \cdot 73^{\mathrm{a}}$ & $1 \cdot 33^{\mathrm{ab}}$ & $1 \cdot 52^{\mathrm{a}}$ & $1 \cdot 40$ & $0 \cdot 05$ \\
\hline \hline
\end{tabular}

C, control; DN, after $24 \mathrm{~h}$ food deprivation, non-adapted; RN, after $24 \mathrm{~h}$ food restoration, non-adapted; D, after $24 \mathrm{~h}$ food deprivation, adapted; $\mathrm{R}$, after $24 \mathrm{~h}$ food restoration, adapted.

a,b,c Mean values in horizontal rows (treatment means combining 1 and $2 \mathrm{~h}$ after injection) with different superscript letters were significantly different $(P<0.05)$.

$\dagger$ Calculated from analysis of variance (forty birds).

$2 \mathrm{~h}$ after the injection. It increased after $24 \mathrm{~h}$ of food deprivation above the control level but was not significantly different from that of the controls after $24 \mathrm{~h}$ of refeeding (significantly only in DN birds, Table 1).

In the pancreas, $2 \mathrm{~h}$ after injection, a significant decrease in the level of the bound $\left[{ }^{14} \mathrm{C}\right]$ lysine was noted on the day of food restoration ( $\mathrm{R}$ and $\mathrm{RN}$ birds). The level of the bound $\left[{ }^{14} \mathrm{C}\right]$ lysine was less than that of the controls after food deprivation and exceeded that of the controls after refeeding $\left(1 \mathrm{~h}\right.$ after injection, not significant). The level of free $\left[{ }^{14} \mathrm{Cllysine}\right.$ decreased significantly $2 \mathrm{~h}$ after injection in all treatment groups (except for D); no significant differences between treatment groups were noted.

In the GIT segments (crop, duodenum, jejunum and ileum), the level of the bound $\left[{ }^{14} \mathrm{C}\right]$ lysine was not affected significantly by the time-interval after injection. The intestinal segments, duodenum, jejunum and ileum were affected by the treatments. The level of the bound $\left[{ }^{14} \mathrm{C}\right]$ lysine was reduced below the control level in DN but not significantly different from the controls in RN chicks. In the adapted birds a similar trend was observed but the differences were smaller and not significant. The free $\left[{ }^{14} \mathrm{C}\right] l y s i n e$ level decreased significantly $2 \mathrm{~h}$ after injection in the ileum but not in the duodenum and jejunum (Table 1).

Bound : free $\left[{ }^{14} \mathrm{C}\right]$ lysine was affected by treatment and the magnitude of this ratio varied among organs in the same way as the bound $\left[{ }^{14} \mathrm{C}\right]$ lysine (Table 2). In all tissues assayed, bound : free $\left[{ }^{14} \mathrm{C}\right]$ lysine was lower in D, DN and higher in R, RN chicks when compared with $C$ (jejunum and ileum in the refed chick excepted) (Table 2). The ratio was higher in adapted than in non-adapted chicks on days of food deprivation but not on days of refeeding.

\section{DISCUSSION}

The rate of protein synthesis was higher in the pancreas and intestinal segments than in the liver, kidneys and muscles. This is in accord with the finding that protein turnover during $24 \mathrm{~h}$ in rat was $70 \%$ in GIT, $60 \%$ in liver and $10 \%$ in skeletal muscle (Millward, 1979). The tissues assayed in the present study could be divided into three categories according to the increase or decrease of bound $\left[{ }^{14} \mathrm{C}\right]$ lysine after injection: (1) skeletal muscles, in which synthesized proteins accumulated and therefore an increase of bound $\left[{ }^{14} \mathrm{C}\right]$ lysine occurred 
with time; (2) the GIT segments, kidneys and liver, which are secreting organs in which equilibrium was obtained between synthesis and secretion of proteins $1 \mathrm{~h}$ after injection and therefore the level of bound lysine did not change between 1 and $2 \mathrm{~h}$ after injection; (3) the pancreas, in which the marked increase in bound $\left[{ }^{14} \mathrm{C}\right]$ lysine $1 \mathrm{~h}$ after injection in $\mathrm{RN}$ and $\mathrm{R}$ chicks was probably due to the enhanced protein synthesis in refed birds (Gertler \& Nitsan, 1970) and to the incorporation of the marker into both precursors of digestive enzymes and digestive enzymes.

It is suggested that the marked reduction in labelled proteins $2 \mathrm{~h}$ after injection in the pancreas of refed birds was due to a higher secretion than synthesis. In the D chicks, an opposite trend was observed since in this state the secretion of digestive enzymes is negligible and they accumulate in the pancreas (Gertler \& Nitsan, 1970; Nir \& Nitsan, 1979). Food deprivation was accompanied by a reduced protein synthesis in the intestinal segments (duodenum, jejunum and ileum) in non-adapted chicks only. In these chicks the intestine is empty after $24 \mathrm{~h}$ of food deprivation while in adapted chicks chyme is present in the intestine for over $24 \mathrm{~h}$ after food removal (Nir \& Nitsan, 1979). The presence of chyme in the intestine may be associated with a higher level of intestinal mucosa and enzyme production, which may explain the higher rate of protein synthesis in the intestinal wall.

Intermittent feeding is accompanied by changes in breast muscle growth rate and composition (Pinchasov, 1985). On days of food deprivation breast muscle weight is reduced due to tissue degradation in order to supply energy and protein for maintenance. On days of food restoration breast muscle growth exceeds that in ad lib.-fed birds by a greater amount in adapted birds than in those not adapted to intermittent feeding (Pinchasov et al. 1987). Protein synthesis in breast muscle varies accordingly: the bound $\left[{ }^{14} \mathrm{C}\right]$ lysine was higher on days of refeeding and lower on days of food deprivation, compared with ad lib.-fed counterparts (Table 1). This increase was more pronounced in adapted than in non-adapted chickens. The same conclusion was proposed in a previous study (Pinchasov et al. 1987), since the levels of RNA and RNA :DNA ratio in muscles were higher in repleted than in depleted chicks and in adapted than in non-adapted birds. A relation between RNA concentration and protein synthesis was reported in rats in vitro (Li \& Goldberg, 1976) and in chicks in vivo (MacDonald \& Swick, 1981). Sunde et al. (1984) showed that protein synthesis in breast and leg muscles decreased with age as growth rate is reduced.

In the present work a relation between muscle growth and protein synthesis (incoporation of $\left[{ }^{14} \mathrm{C}\right]$ lysine into proteins) has been discussed. It was also shown that there are short- and long-term adaptations of protein synthesis to feeding regimens. The short-term adaptation is shown by the marked increase in $\left[{ }^{14} \mathrm{C}\right]$ lysine incorporation on the day of refeeding after a day of food deprivation, while the long-term adaptation is shown by the higher rate of $\left[{ }^{14} \mathrm{C}\right]$ lysine incorporation in the refed birds adapted to intermittent feeding when compared with non-adapted chicks.

The authors thank Mrs M. Barak and Z. Zoref for their technical assistance. This work was supported by grant no. 1-89-79 from the US-Israel Binational Agricultural Research and Development Fund (BARD). 
MacDonald, M. L. \& Swick, R. W. (1981). Biochemistry Journal 194, 811-819.

Millward, D. J. (1979). Proceedings of the Nutrition Society 38, 77-88.

National Research Council (1977). Nutrient Requirements of Poultry 7th ed. Washington DC: National Academy of Science.

Nie, N. H., Hull, C. H., Jenkins, J. G., Steinbrenner, K. \& Bent, D. H. (1975). Statistical Package for the Social Sciences (SPSS), 2nd ed. New York: McGraw-Hill.

Nir, I. \& Nitsan, Z. (1979). British Poultry Science 20, 61-71.

Pinchasov, Y. (1985). The contribution of skeletal muscles to compensatory growth of chickens exposed to intermittent feeding. PhD. Thesis, The Hebrew University of Jerusalem.

Pinchasov, Y., Nir, I. \& Nitsan, Z. (1985).Poultry Science 64, 2098-2109.

Pinchasov, Y., Nir, I. \& Nitsan, Z. (1987). Annals of Nutrition and Metabolism 31, 362-366.

Sunde, M. L., Swick, R. W. \& Kang, C. W. (1984). Poultry Science 63, 2055-2061. 